RESPONSE OF CERTAIN WINTER WHEAT VARIETIES

TO STAND DENSITY

by

JTMYY MABRY

B. S., Texas Technological College, 1962

A MASTER'S THESIS

submitted in partial fulfillment of the

requirements for the degree

MASTER OF SCIENCE

Department of Agronomy

KANSAS STATE UNIVERSITY

Manhattan, Kansas

1964

Approved by:

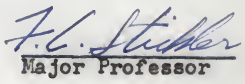




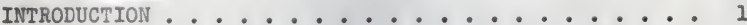

LITERATURE REVIEW ............. 2

Seeding Rate .............. 2

Plant Spacing And Yield Components ...... . 4 METHODS AND MATERIALS ............ 7 EXPERTMENTAL RESULTS ............ 8

Seeding Rate Experiment ........... 8

Yield Per Acre .......... 8

Number Of Heads Per Square Foot ....... 12

Number of Seeds Per Head . . . . . . 15

Seed Weight .......... 15

Protein Content of Grain ....... 20

Plant Spacing Experiment ........ 20

Yield Per Acre ........ 20

Yield Per Plant .......... 26

Number of Heads Per Square Foot . . . . . 29

Number Of Seeds Per Head . . . . . . 29

Seed Weight .......... 29

Protein Content of Grain ........ 36 DISCUSSION . . . . . . . . . . . 39 SUMMARY AND CONCLUSIONS ............... 45 ACKNOWLEDGMENT ........................ 47 ITTERATURE CITED ...................... 48 
INTRODUCTION

Seeding rate has long been considered important in winter wheat culture. Today seeding rates have been well established in the major wheat producing regions. Since these seeding rates are based largely on older studies, it is of interest to determine if they are satisfactory for recently developed varleties.

Optimum seeding rates and the responses to various rates for varieties known to differ rather widely in morphology are worthy of study, since little information is avallable. Consideration of varietal reactions to sub-optimum seeding rates is also important.

Another point of interest is the influence of plant density on the yield components (heads per unit area, seeds per head, seed weight) of different varieties and the importance of each component in determining yield.

The performance of varieties in space planted studies in relation to fleld performance is of particular interest to the plant breeder.

The present study was undertaken to investigate the influence of seeding rate and plant spacing on yleld and yleld components of $81 x$ winter wheat varieties. 
LITERATURE REVIEW

\section{Seeding Rate}

The optimun rate for sowing winter wheat has long been the object of much research. In 1888 , H1ckman (15) reported flve to seven pecks per acre to be the optimum seeding rate in Oh10. Two or three pecks were inferior whlle there was a slight reduction in yield with eight or nine pecks. In Indiana, Latta (21) found that $s i x$ to eight pecks per acre produced maximum yield. Four or five pecks resulted in slightly lower yield, and two or three pecks caused a sharp reduction in y1eld. In IIlinols, Norrow and Gardner (31) found four to eight pecks per acre to give about the same yleld and suggested that five pecks were adequate. Three pecks resulted in yield considerably below those from the higher rates. Georgeson (10) reported elght pecks per acre to be the optimum seeding rate in an early eastern Kansas study. However, later work by Ten Eyck and Shoesmith (42) and St1ckler (41) shows five or six pecks to be adequate in eastern Kansas.

Early work showed the optimum seeding rates for drier areas to be somewhat lower than those for the more humid regions. Morrow and Bone (30) found four to $s i x$ pecks per acre to produce maximum yield in central Oklahoma. In Nevada, NeDowell (28) reported five to $s i x$ pecks per acre to be the optimum seeding rate. Moss (32) found four pecks per acre to produce maximum yleld in an Idaho study. Seeding rate recommendations in New Mexico were two and one-half to three and one-half pecks per acre under dry farming conditions and four to $s 1 x$ pecks under irrigation (40). 
Later work has produced about the same results as that found by the earlier workers in this country. Optimum seeding rates In drier regions are considered to be from four to six pecks per acre $(5,19,22,26,27)$. However, some work has shown that the optimum seeding rate in drier areas may be as high as elght or as low as two pecks per acre $(38,39,41)$. In the more humid regions, seeding rates of five to nine pecks per acre are considered to produce maximum yields $(2,24,25,27,34,43)$.

Winter wheat seeding rates in other parts of the world differ little from those used in comparable areas of the United States. In Ontar10, Canada, Zavitz (45) reported six to seven pecks per acre to be the optimum rate. Glynne and Slope (11) reported twelve pecks per acre to produce maximum ylelds of two varieties in a three year test in England. However, in reviewing English data, Percival (35) and Boyd (3) concluded that the opt1mum seeding rate in that country is about eight pecks per acre. Four to six pecks per acre was considered by Forster (9) to be the optimum seeding rate in moat of Australia.

One obvious fact brought out by most winter wheat seedingrate studies is that there may be a relatively wide range in rates without materially effecting yleld $(24,27,31,36,43)$. However, using seeding rates below the optimum usually produces a much larger reduction in yleld than does an equal amount above the optimum $(3,19,21,26,30,31,43)$. Rates below three pecks per acre in the drier areas and below four pecks in the more humid areas of th1s country have been shown to be almost always inferfor to $\mathrm{h}$ igher rates $(10,15,19,24,25,26,31,43)$. 
The relatively wide range of seeding rates used in any one general location can be largely explained by the ability of the wheat plant to adjust by tillering and changes in head size and seed weight $(5,13,26,34)$. However, many other factors have important roles in determining seeding rates. The variety, kernel size, germination percentage, and seedling vigor of each lot of seed contribute to the actual stand established $(10,16,24,35)$. Seedbed preparation and the method and time of sowing must be considered $(17,35)$. Climatic differences from year to year and soil type and fertility variations from field to field are also 1mportant factors influencing seeding rates $(3,4,16,35)$.

\section{Plant Spacing and Yield Components}

Grantham (12) studied ten varieties at spacings of 10,20 , and 40 seeds per foot of row. Depending on the variety, plants grown at ten seeds per foot had two to three times as many heads per plant as those grown at 40 per foot. The yield per head at the thinnest spacing was almost twice that at the thickest. In another experiment, Grantham (13) found that increasing the seedIng rate from four pecks per acre to eight pecks decreased the number of heads per plant about 40 per cent and the yleld per head was reduced about 25 per cent. Yield per plant was reduced about 48 per cent. The yield per acre was about the same for both rates.

Montgomery (29) showed that although the number and size of heads per plant and yleld per plant rise rapidly with increased area per plant, the yield per unit area of land may decrease. 
He studied spacings of two, one, one-half, and one-fourth inches per plant in eight inch rows. The yield per plant at the twoInch spacing was 4.10 grams compared to .91 grams for the onefourth inch spacing. However, the yleld per plot was 165 grams for the two-inch spacing and 238 grams for the one-fourth inch spacing. Percival (35) obtained similar results with plant spacings ranging from $6 \times 1$ to $24 \times 24$ inches. The number and size of heads and yield per plant Increased with increased spacing; however, the yleld per acre dropped rapidy due to reduced plant population. Buffum (4) and Nelson (33) reported similar results with spring wheat. W1lson and Swanson (44) found that lowering the plant population below flfteen plants per square foot resulted in a significant reduction in yield per acre.

The number of seeds per head has been shown to Increase as plant density is decreased or as the number of heads per square foot is decreased $(1,5,8,35,41)$.

Test weight was found to increase with increased plant population by Wilson and Swanson (44). Kinra et al. (20) reported test welght to increase slightly with higher seeding rates in two tests while there were no signiflcant differences in two other tests. Zavitz (45) found no significant changes in test weight due to seeding rate.

In general, weight per kernel increases with increased plants per acre $(5,12,13,14,31)$. However, others have reported no influence of seeding rate on kernel welght $(8,24,44)$. Stickler (41) reported a reduction in kernel welght with increased seeding rate one year and a rise the next year. Ahmed (I) found a slight 
decrease in kemel weight as seeding rate was increased.

High seeding rates often result in hastening maturity $\{4,13$, 44). Plant helght may be decreased by increasing plant population $(4,5,13,44)$.

There may be considerable varietal differences in response to seeding rate or plant spacing $(8,12,13,14)$. In extensive seeding rate and plant spacing studies with a large number of varleties, Grantham (13) found wide differences in the tillering and yield responses of different varleties. However, Ahmed (1) reported the influence of various seeding rates and plant spacings to be similar for six varieties in a one-year study. Gultard (14) found only slight differences in the response of two varieties of spring wheat to seeding rates at three locations.

Kinra et a1. (20) and Ahmed (1) reported a decrease in protein content of grain as plant density was increased. However, Pendleton and Dungan (34) found seeding rate to have no effect on grain protein and $\mathrm{Kiesselbach}$ et 21 . (18) reported an increase in protein with increased seeding rate. 


\section{METHODS AND MATERIALS}

During 1962-63, a sesding rate and a plant spacing study with winter wheat was conducted on the Agronomy Farm at Manhattan, Kansas.

The experiments were conducted on a light silty clay loam so11 having an unusually thick (16 to 24 inches) A horizon. The preceding crop was oats. A mixture of $16-48-0$ and $33 \cdot 5-0-0$ fert1lizer providing approximately 49 and 20 pounds of nitrogen (N) and phosphorus $(P)$, respectively, per acre was applied prior to planting. Planting was done on Cctober 9 with Planet, Jr., 300-A seeders. Germination of the seed was determined in order to accurately callbrate the varlous seeding rates.

Both experiments were conducted in a split plot design with four replications. The main plots were the $s i x$ winter wheat varleties: Blson, Cheyenne, Kaw, Ottawa, Pawnee, and Triumph. The sub plot treatments in the seeding rate experiments were seedIng rates of $6,12,18,24$, and 30 viable seeds per foot of row (12inch rows). These rates were equivalent to approximately 30, 50, 70,90 , and 110 pounds of seed per acre, respectively. The final stands of Blson, Cheyenne, and Trlumph were slightly below the stands of the other three variet1es. In the plant spacing experiment, the sub plot treatments were spacings of $6,9,12$, and 15 inches between plants in the row (12-inch row). This experiment was seeded at approximately 30 pounds per acre and the plants were thinned by hand to the desired stand.

Each sub plot consisted of four 12-foot rows. Nine feet of 
the two center rowa were harvested for yield. Head counts were made from a three-foot section of the center rows in the seeding rate experiment. In the space-planted experiment, the heads on five plants were counted. Weeding was done in April.

The wheat was harvested by hand, dried, threshed, and welghed. Seed weight was determined by counting and welghing 200 seeds from each sub plot. The number of seeds per head was determined from seed welght, heads per square foot, and sub plot yield data. After grinding, the protein percentage of the grain was determined by the $\mathrm{KJeldahl}$ method. Percentages were determlned on an oven-dry basis. Statistical analysis was done according to procedures outlined by Snedecor (37) and LeClerg et al. (23).

EXPERTMENTAL RESULTS

Seeding Rate Experiment

Sources of variation, degrees of freedom, and mean squares in the analysis of variance for the seeding rate experiment are given in Table 1.

Yleld Per Acre. The yields for the different variety and seedIng rate combinations are given in Figure 1 and Table 2. Analysis of varlance showed that differences among varleties and among seeding rates were significant at the one per cent level of probability. The yields of Ottawa and Kaw were significantly (five per cent level) higher than those of Triumph and Pawnee. Bison and Cheyenne yielded signifleantly less than Ottawa, Kaw, Triumph, and Pawnee. Highest yields of Cheyenne and Trlumph were produced at the seeding rate of 24 viable seeds per square foot while the maximum yields 


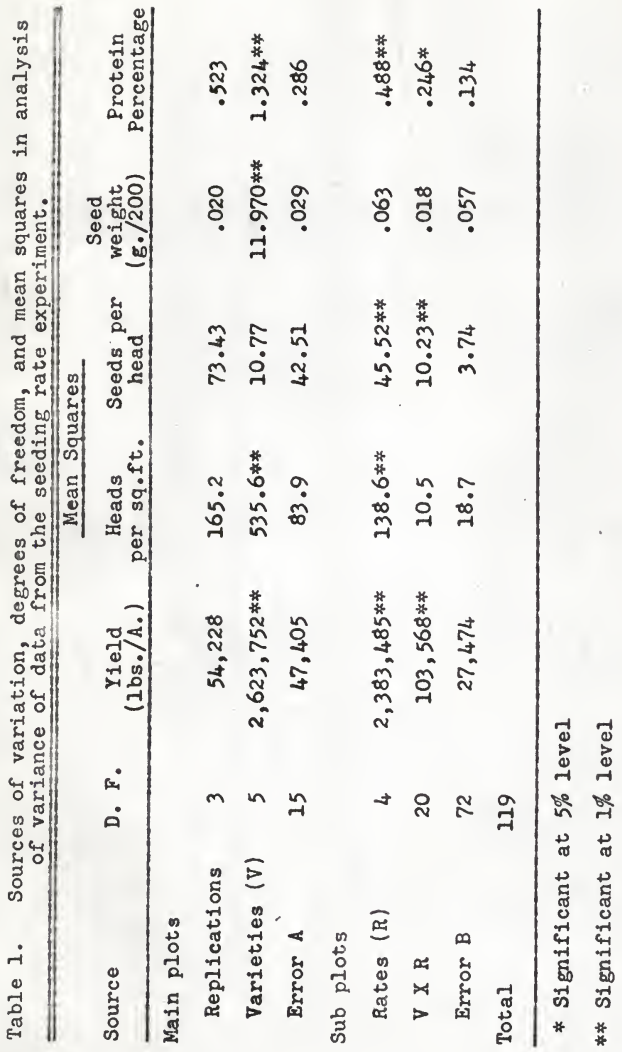




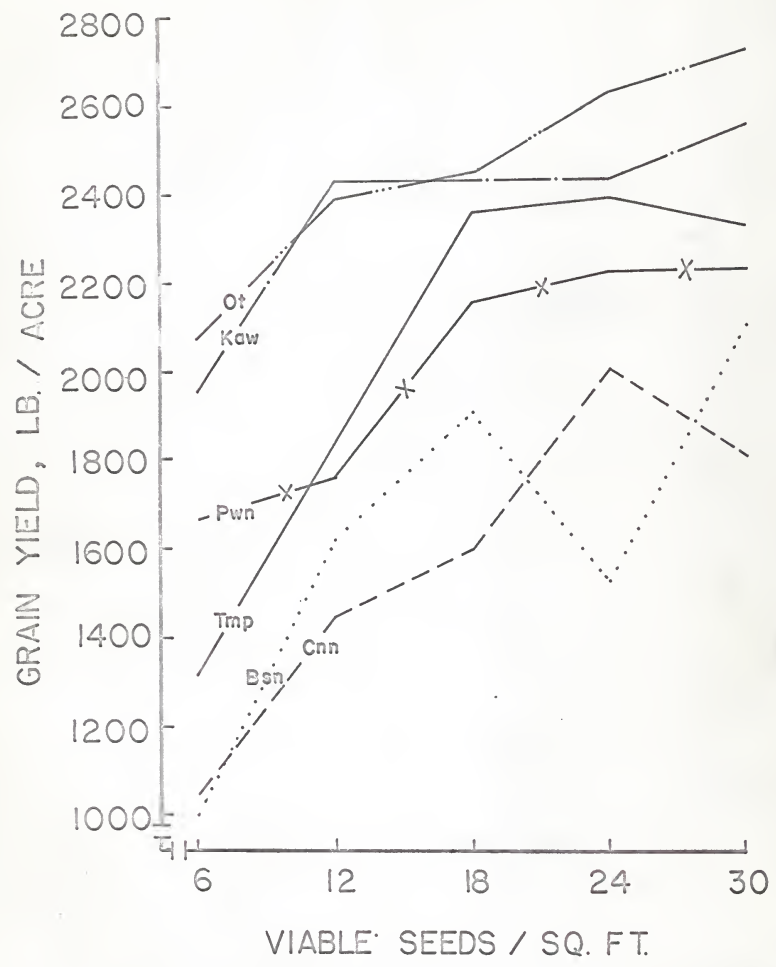

Figure 1. Influence of variety and seeding rate on grain yield. 
Table 2. Influence of variety and seeding rate on grain yield (pounds per acre).

\begin{tabular}{|c|c|c|c|c|c|c|c|c|}
\hline \multirow{2}{*}{ Variety } & \multirow{2}{*}{$\vdots$} & \multicolumn{5}{|c|}{ Viable seeds per sq. $f t$. } & \multirow{2}{*}{ : } & \multirow{2}{*}{$\begin{array}{c}\text { Variety } \\
\text { mean }\end{array}$} \\
\hline & & 6 & 12 & 18 & 24 & 30 & & \\
\hline Bison & : & 998 & 1616 & 1907 & 1521 & 2110 & $\vdots$ & 1630 \\
\hline Cheyenne & : & 1040 & 1447 & 1597 & 2005 & 1810 & $\vdots$ & 1580 \\
\hline Kaw & : & 1960 & 2430 & 2432 & 2432 & 2562 & $\vdots$ & 2363 \\
\hline Ottawa & : & 2078 & 2392 & 2455 & 2633 & 2730 & $\vdots$ & 2458 \\
\hline Pawnee & $\vdots$ & 1671 & 1760 & 2151 & 2228 & 2234 & $\vdots$ & 2009 \\
\hline Triumph & $\vdots$ & 1314 & 1836 & 2357 & 2382 & 2338 & $\vdots$ & 2045 \\
\hline $\begin{array}{l}\text { Seeding } \\
\text { rate mean }\end{array}$ & : & 1510 & 1914 & 2150 & 2200 & 2297 & $\vdots$ & \\
\hline
\end{tabular}

ISD at $5 \%$ level

Varieties $=147$

$$
\text { Rates }=95
$$

Varieties within each rate $=255$

Rates within

each variety $=74$

Variety Ottawa Kaw Triumph Pawnee Bison Cheyenne

\begin{tabular}{llllll} 
Ranking $\quad 2458 \quad 2363$ & $2045 \quad 2009$ & 1630 & 1580 \\
\hline
\end{tabular}

$\begin{array}{llllll}\text { Rate } & 30 & 24 & 18 & 12 & 6\end{array}$

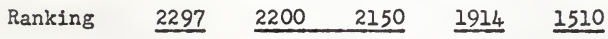

Means underscored by the same line are not significantly (5\% level) different. 
of Bison, Kaw, Ottawa, and Pawnee were obtained with 30 viable seeds per square foot. Kaw, Ottawa, and Pawnee gave Increased yleld with each increase in seeding rate. Triumph yleld increased rapidly as the seeding rate was increased to 18 viable seeds per square foot and then showed l1ttle difference at 18, 24, and 30 viable seeds per square foot. In comparing the yleld of these varleties, it should be remembered that the actual fleld stands of Blson, Cheyenne, and Triumph were somewhat less than those of Kaw, Ottawa, and Pawnee.

There were significant increases in yield as the seeding rate increased with the exception of the increase from 18 to 24 viable seeds per square foot. The largest single increase in yleld occurred between the 6 and 12 viable seeds per square foot rate.

The variety $x$ seeding rate interaction was significant at the one per cent level. Much of this interaction was attributed to the drop in yleld at 30 viable seeds per square foot for Cheyenne and the low yleld of Bison at 24 viable seeds per square foot. Also, the yields of Bison, Cheyenne, and Triumph were reduced much more by thin seeding than were the ylelds of Kaw, Ottawa, and Pawnee.

Number of Heads Per Square Foot. The influence of varlety and seeding rate on the number of heads per square foot is shown in Figure 2 and Table 3. Varlety and seeding rate effects were both signifleant at the one per cent level. No signiflcant varlety $x$ seeding rate Interaction was detected. Ottawa and Pawnee had 81gnificantly more heads per square foot than Cheyenne, Triumph, and Bison. Kaw had significantly fewer heads per square foot than Ottawa but did not differ significantly from Pawnee, Cheyenne, 


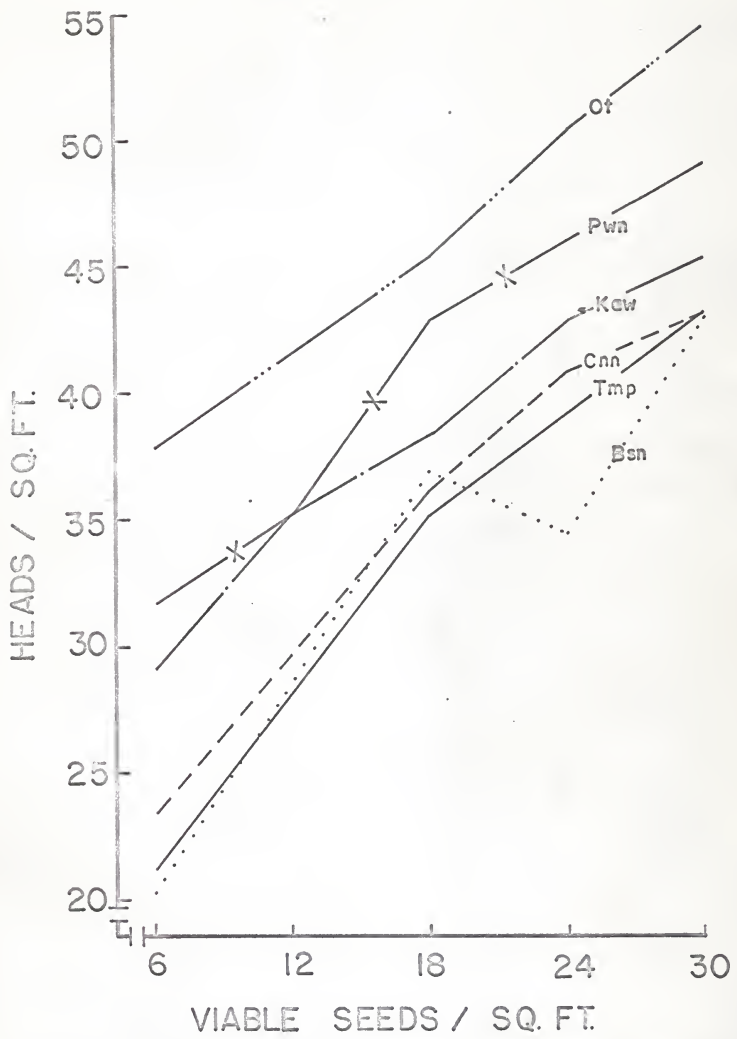

Figure 2. Influence of variety and seeding rate on number of heads per square foot. 
Table 3. Influence of variety and seeding rate on the number of heads per square foot.

\begin{tabular}{|c|c|c|c|c|c|c|c|c|}
\hline \multirow[t]{2}{*}{ Variety } & \multicolumn{3}{|r|}{ Viable } & \multicolumn{3}{|c|}{ seeds per sq. ft. } & \multirow{2}{*}{ : } & \multirow{2}{*}{$\begin{array}{c}\text { Variety } \\
\text { mean }\end{array}$} \\
\hline & $:$ & 6 & 12 & 18 & 24 & 30 & & \\
\hline Bison & : & 20.2 & 28.6 & 36.8 & $34 \cdot 4$ & 43.0 & : & 32.6 \\
\hline Cheyenne & : & 23.4 & 29.6 & 36.1 & 40.8 & 43.2 & $\vdots$ & 34.6 \\
\hline Kaw & $:$ & 29.1 & 35.3 & 38.3 & 42.9 & 45.3 & $\vdots$ & 38.2 \\
\hline Ottawa & : & 37.8 & 41.5 & 45.4 & 50.4 & $54 \cdot 5$ & $\vdots$ & 46.0 \\
\hline Pawnee & $:$ & 31.6 & 35.2 & 42.8 & 46.0 & 49.1 & $\vdots$ & 41.0 \\
\hline Triumph & $:$ & 21.2 & 28.3 & 35.2 & 39.1 & 43.2 & $\vdots$ & 33.4 \\
\hline $\begin{array}{l}\text { Seeding } \\
\text { rate mean }\end{array}$ & : & $27 \cdot 2$ & 33.1 & 39.1 & 42.3 & 46.5 & : & \\
\hline
\end{tabular}

LSD at $5 \%$ level Varieties $=6.2$

$$
\text { Rates }=2.5
$$

Variety Ottawa Pawnee Kaw Cheyenne Triumph Bison.

$\begin{array}{lllllll}\text { Ranking. } & 46.0 & \frac{41.0}{38.2} & 34.6 & 33.4 & 32.6 \\ \text { Rate } & 30 & 24 & 18 & 12 & 6 & \end{array}$

Ranking $46.5 \quad 42.3 \quad 29.1 \quad 23.1 \quad 27.2$

Means underscored by the same line are not significantly (5\% level) different. 
Trlumph, and Blson. All varieties except Bison showed an Increase in heads per square foot with each increase in seeding rate.

A signifleant increase in heads per square foot was obtained with each increase in seeding rate. The increases in number of heads per square foot as the seeding rate increased from 6 to 12 and 12 to 18 viable seeds per square foot were about twice the Increase that occurred from 18 to 24 and 24 to 30 viable seeds per square foot.

Number of Seeds Per Head. Information on seeds per head is presented in Figure 3 and Table 4. There were no significant differences between varleties, and seeding rate alfferences were significant at the one per cent level. The seeding rate of 12 viable seeds per square foot resulted in number of seeds per head significantly higher than the other rates. The 6,12 , and 18 viable seeds per square foot rates produce signifleantly more seeds per head than the 24 and 30 rates. Thus, in general, the number of seeds per head Increased as the seeding rate decreased.

The variety $x$ seeding rate Interaction was slgniflcant at the one per cent level. This was attributed largely to the inconsistent response of Bison, Cheyenne, and Kaw.

Seed Weight. Figure 4 and Table 5 show the influence of variety and seeding rate on seed welght. Differences due to varleties were signiflcant at the one per cent level while there were no signifleant differences due to seeding rate. Kaw and Triumph had seed weights significantly greater than the other varieties. The seeds of Ottawa and B1son were significantly heavier than either 


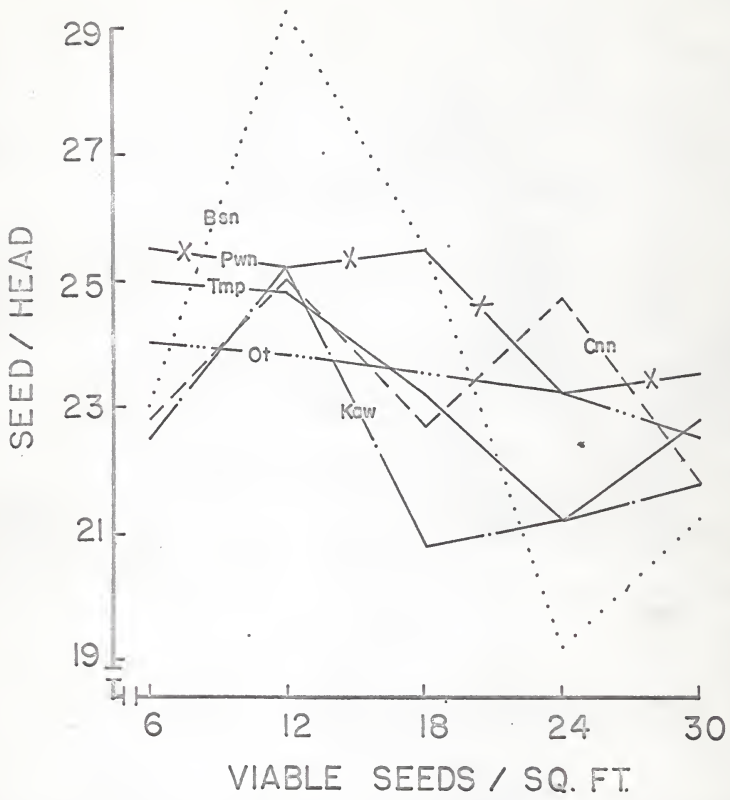

Figure 3. Influence of variety and seeding rate on number of seeds per head. 
Table 4. Influence of variety and seeding rate on number of seeds per head.

\begin{tabular}{|c|c|c|c|c|c|c|c|c|}
\hline \multirow{2}{*}{ Variety } & \multirow{2}{*}{ : } & & Viable & \multicolumn{2}{|c|}{ seeds per sq. } & \multirow{2}{*}{ ft. } & \multirow[t]{2}{*}{ 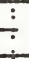 } & \multirow{2}{*}{$\begin{array}{c}\text { Variety } \\
\text { mean }\end{array}$} \\
\hline & & 6 & 12 & 18 & 24 & & & \\
\hline Bison & $\vdots$ & 23.0 & 29.2 & 25.5 & 19.2 & 21.2 & $\vdots$ & 23.6 \\
\hline Cheyenne & $\vdots$ & 22.8 & 25.0 & 22.7 & 24.7 & 21.8 & $\vdots$ & 23.4 \\
\hline Kaw & $\vdots$ & 22.5 & 25.2 & 20.8 & 21.2 & 21.8 & $\vdots$ & 22.3 \\
\hline Ottawa & $\vdots$ & 24.0 & 23.8 & 23.5 & 23.2 & 22.5 & $\vdots$ & 23.4 \\
\hline Pawnee & : & 25.5 & 25.2 & 25.5 & 23.2 & 23.5 & $\vdots$ & 24.6 \\
\hline Triumph & : & 25.0 & 24.8 & 23.2 & 21.2 & 22.8 & $\vdots$ & 23.4 \\
\hline $\begin{array}{l}\text { Seeding } \\
\text { rate mean }\end{array}$ & $:$ & 23.8 & 25.5 & 23.5 & 22.2 & 22.2 & $\vdots$ & \\
\hline
\end{tabular}

LSD at $5 \%$ level

$$
\text { Rates }=1.1
$$

Rates within

each variety $=2.7$

Varieties within

$$
\text { each rate }=5.0
$$

Variety Pawnee Bison Cheyenne Ottawa Triumph Kaw

\begin{tabular}{lllllll} 
Ranking & 24.6 & 23.6 & 23.4 & 23.4 & 23.4 & 22.3 \\
\hline
\end{tabular}

$\begin{array}{llllll}\text { Rate } & 12 & 6 & 18 & 24 & 30\end{array}$

Ranking $25.5 \quad \underline{23.8} \quad 23.4 \quad 22.2 \quad 22.2$

Means underscored by the same line are not significantly ( $5 \%$ level) different. 


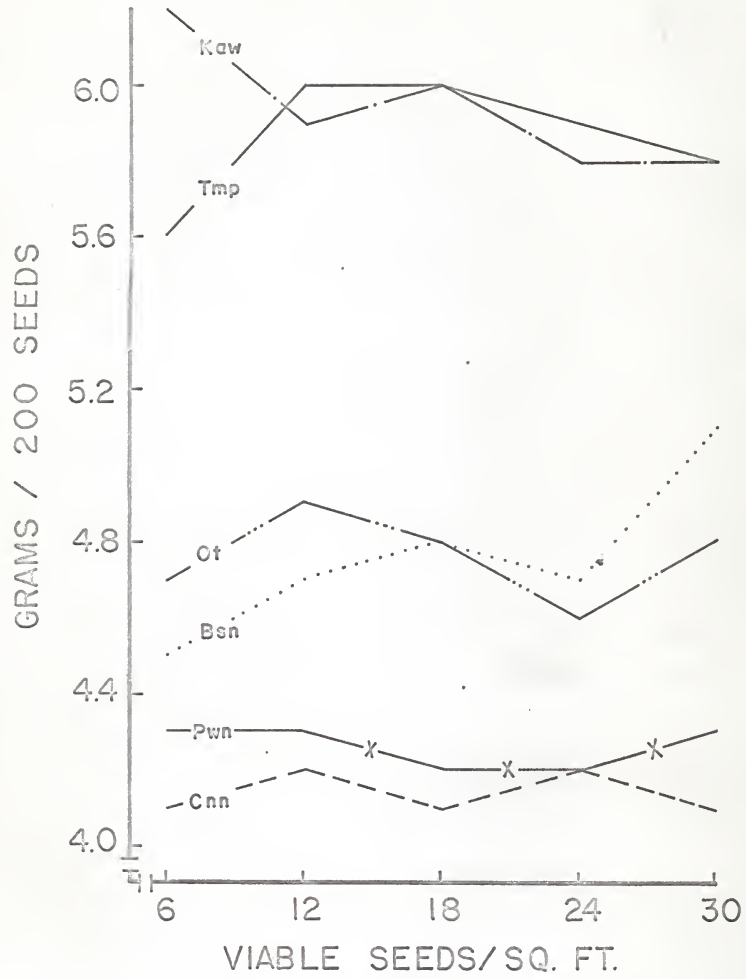

Figure 4. Influence of variety and seeding rate on seed welght. 
Table 5. Influence of variety and seeding rate on the weight of 200 seeds (grams).

\begin{tabular}{|c|c|c|c|c|c|c|c|c|}
\hline \multirow{2}{*}{ Variety } & & \multicolumn{5}{|c|}{ Viable seeds per sq. ft. } & \multirow[t]{2}{*}{ : } & \multirow{2}{*}{$\begin{array}{c}\text { Variety } \\
\text { mean }\end{array}$} \\
\hline & : & 6 & 12 & 18 & 24 & 30 & & \\
\hline Bison & : & 4.51 & 4.74 & 4.84 & 4.72 & 5.11 & $:$ & 4.78 \\
\hline Cheyenne & $\vdots$ & 4.06 & 4.19 & 4.11 & 4.19 & 4.08 & $\vdots$ & 4.13 \\
\hline Kaw & $:$ & 6.15 & 5.86 & 5.99 & 5.84 & 5.84 & $:$ & 5.93 \\
\hline Ottawa. & $\vdots$ & 4.73 & 4.87 & 4.85 & 4.65 & 4.83 & : & 4.79 \\
\hline Pawnee & $\vdots$ & 4.29 & 4.32 & 4.20 & 4.24 & 4.34 & $:$ & 4.28 \\
\hline Triumph & : & 5.65 & 6.02 & 5.96 & 5.86 & 5.85 & : & 5.88 \\
\hline $\begin{array}{l}\text { Seeding } \\
\text { rate mean }\end{array}$ & $:$ & 4.90 & 4.99 & 4.99 & 4.93 & 5.01 & $:$ & \\
\hline
\end{tabular}

ISD at $5 \%$ level Varieties $=.12$

Varieties Kaw Triumph Ottawa Bison Pawnee Cheyenne

$\begin{array}{lllllll}\text { Ranking } \quad 5.93 \quad 5.88 & 4.79 \quad 4.78 & 4.28 & \end{array}$

$\begin{array}{llllll}\text { Rates } & 30 & 18 & 12 & 24 & 6\end{array}$

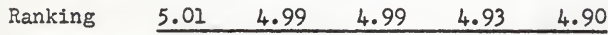

Means underscored by the same line are not significantly (5\% level) different. 
Pawnee or Cheyenne. Kaw produced its heaviest seeds at the lower seeding rates while Bison showed its highest seed weights at the higher seeding rates. The other varieties showed no definite trends. There was no significant varlety $x$ seeding rate interaction.

Protein Content of Grain. The protein percentage of the grain Is shown in Figure 5 and Table 6 . Bison was signifleantly higher than Triumph. The six viable seeds per square foot rate produced significantly more protein than all the other rates. Highest protein content of Bison occurred at six viable seeds per square foot. Cheyenne and Pawnee had highest protein content at the lower seeding rates while the hlghest protein content of Ottawa occurred at the higher rates. Kaw and Triumph failed to show any trend.

The variety $x$ seeding rate Interaction was evident at the Pive per cent level and was attributed to the inconsistent response of all the varleties.

Plant Spacing Experiment

The analysis of variance of data from this experiment is presented in Table 7.

Ileld Per Acre. Varietal differences in yield (Figure 6 and Table 8) were significant at the one per cent level. Yields of Ottawa and Kaw were significantly (five per cent level) higher than those of Triumph, Cheyenne, and Bison. Pawnee was not signifleantly different from Ottawa, Kaw, Triumph, and Cheyenne but was signif1cantly higher than Bison. All varieties produced less grain per 


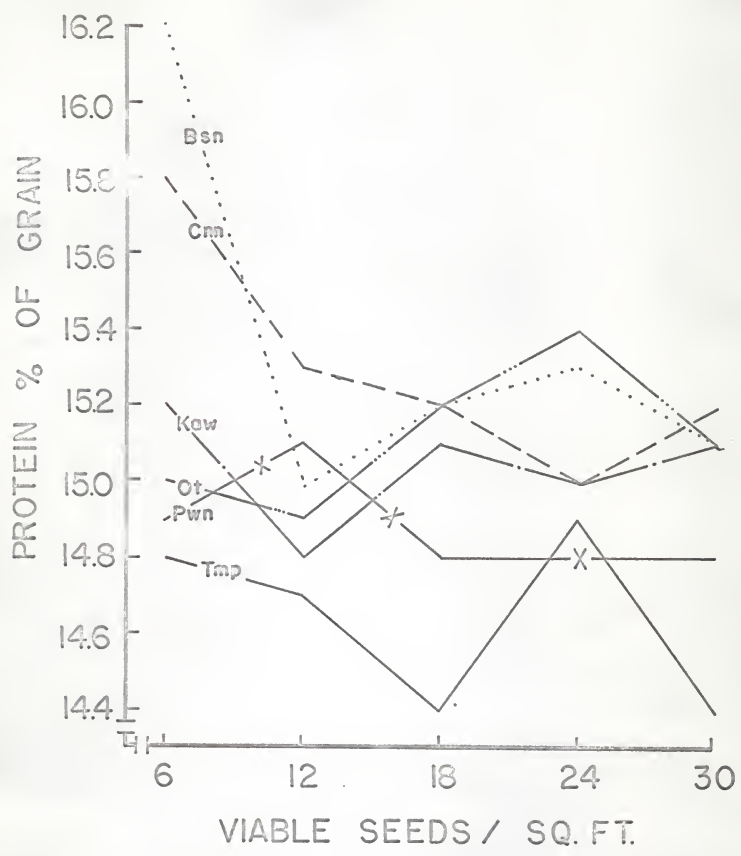

Figure 5. Influence of variety and seeding rate on protein percentage of grain. 
Table 6. Influence of variety and seeding rate on protein percentage of grain.

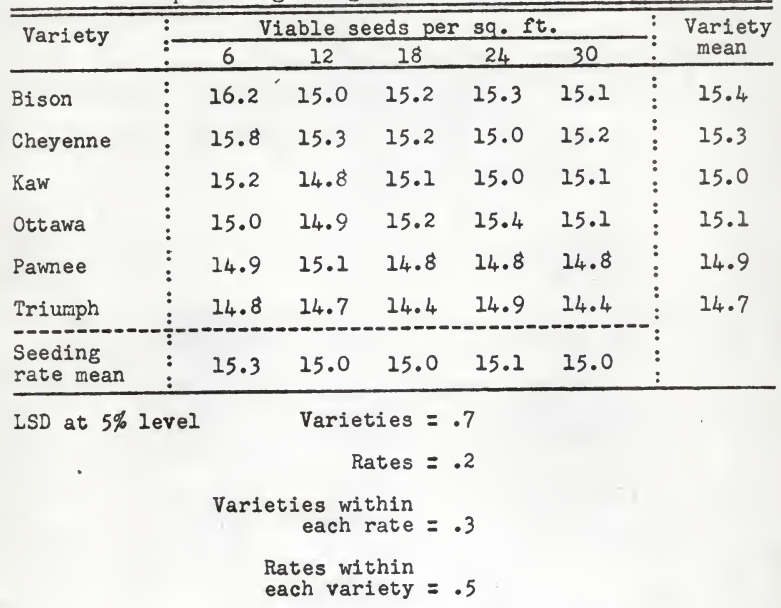

Variety Bison Cheyenne Ottawa Kaw Pawnee Triumph \begin{tabular}{lllllll} 
Ranking & 15.4 & 15.3 & 15.1 & 15.0 & 14.9 & 14.7 \\
\hline
\end{tabular}

$\begin{array}{llllll}\text { Rate } & 6 & 24 & 12 & 18 & 30\end{array}$

\begin{tabular}{llllll} 
Ranking $\quad 15.3$ & 15.1 & 15.0 & 15.0 & 15.0 \\
\hline
\end{tabular}

Means underscored by the same line are not significantly (5\% level) different. 


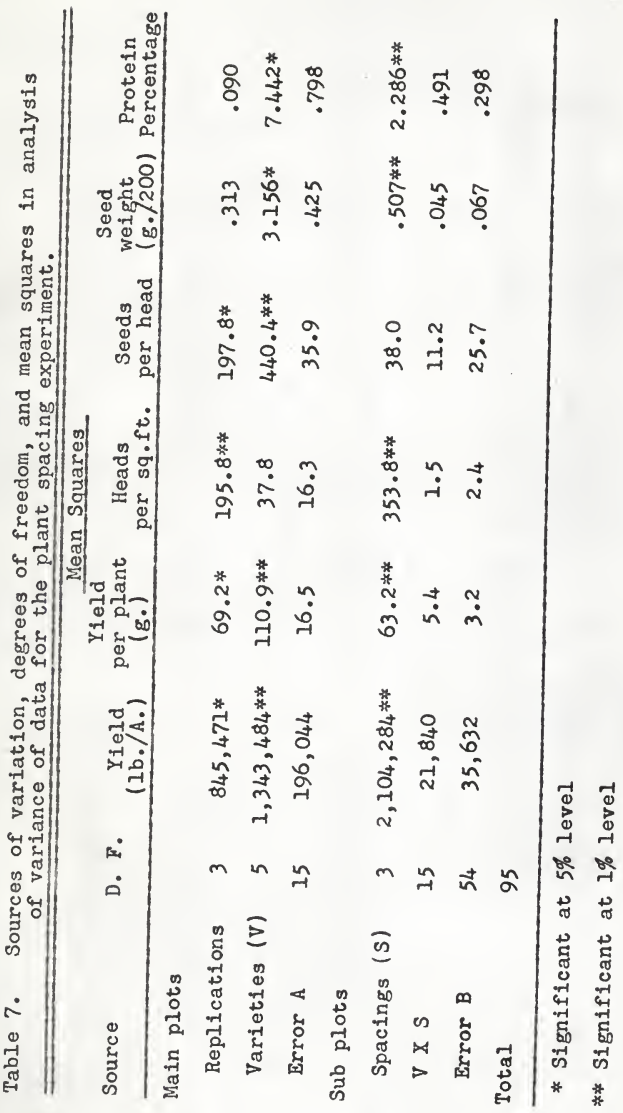




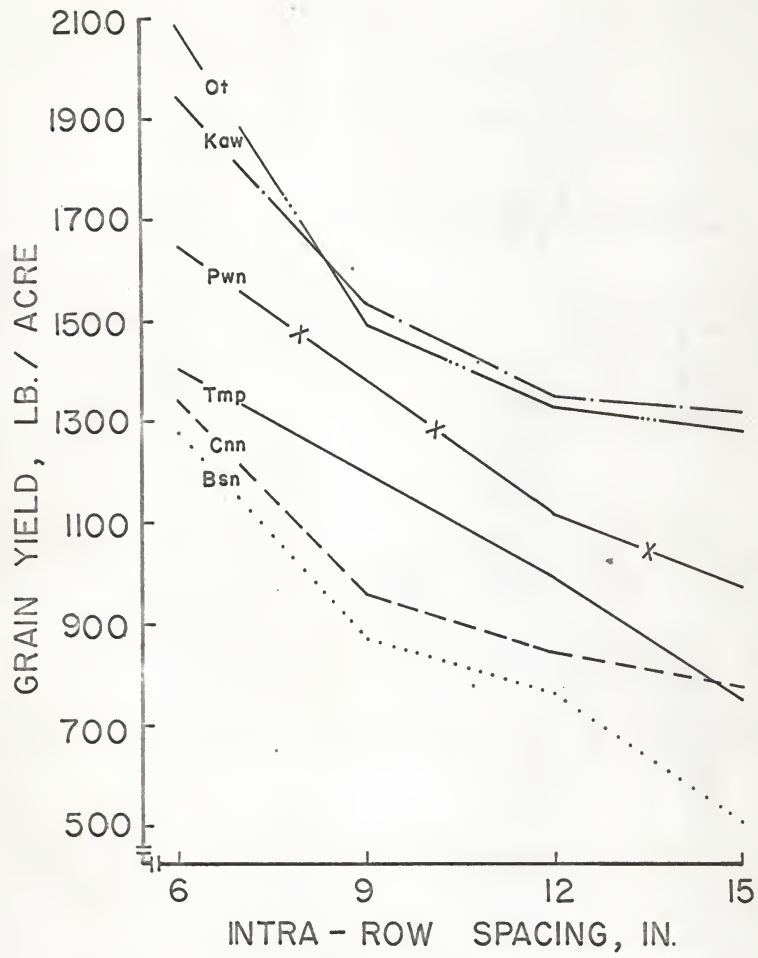

Figure 6. Influence of variety and plant spacing on grain yield. 
Table 8. Influence of variety and plant spacing on grain yield (pounds per acre).

\begin{tabular}{|c|c|c|c|c|c|c|c|}
\hline \multirow{2}{*}{ Variety } & \multirow{2}{*}{$\vdots$} & \multicolumn{4}{|c|}{ Intra-row spacing (inches) } & \multirow{2}{*}{ : } & \multirow{2}{*}{$\begin{array}{c}\text { Variety } \\
\text { mean }\end{array}$} \\
\hline & & 6 & 9 & 12 & 15 & & \\
\hline Bison & $\vdots$ & 1276 & 873 & 758 & 508 & : & 854 \\
\hline Cheyenne & $\vdots$ & 1342 & 958 & 841 & 777 & $\vdots$ & 980 \\
\hline Kaw & $:$ & 1943 & 1533 & 1348 & 1318 & : & 1536 \\
\hline Ottawa & $:$ & 2084 & 1496 & 1326 & 1279 & : & 1547 \\
\hline Pawnee & $:$ & 1647 & 1386 & 1115 & 974 & $\vdots$ & 1281 \\
\hline Triumph & $\vdots$ & 1403 & 1192 & 994 & 750 & : & 1085 \\
\hline $\begin{array}{l}\text { Spacing } \\
\text { mean }\end{array}$ & : & 1615 & 1240 & 1064 & 934 & $\vdots$ & \\
\hline
\end{tabular}

LSD at $5 \%$ level Varieties $=334$

Spacings $=109$

Variety Ottawa Kaw Pawnee Triumph Cheyenne Bison

Ranking

$\begin{array}{lllll}1547 & 1536 & 1281 & 1085 \\ 6 & 9 & 12 & 15\end{array}$

Ranking $\quad \underline{1615} \quad \underline{1240} \quad 1064 \quad 934$

Means underscored by the same line are not significantly (5\% level) different. 
acre as plant spacing increased. The largest decrease in yleld for all varieties except Triumph and Pawnee occurred as spacing was Increased from 6 to 9 inches. Grain yleld of Triumph decreased about the same amount with each spacing increase. Yleld of Pawnee dropped about the same from the 6 to 9 inch spacing as at the 9 to 12-inch spacing and decreased less as the spacing was increased from 12 to 15 inches.

Spacing means were all slgnificantly different at the five per cent level. Yleld decreased rapidiy as the distance between plants was increased. The decrease in yleld as the spacing was ralsed from 6 to 9 inches was over twice those occurring at the other two spacing increases. Varlety $x$ spacing interaction was not noted.

Yleld Per Plant. Data on yleld per plant is given in Figure 7 and Table 9. Differences in yleld per plant due to both variety and plant spacing were signiflcant at the one per cent level. Kaw and Ottawa per plant ylelds were signiflcantly (flve per cent level) higher than Triumph, Cheyenne, and Bison. Pawnee yield per plant did not differ algnifleantly from Kaw, Ottawa, Triumph, and Cheyenne but was significantly higher than Bison. The differences between spacing means were all significant at the five per cent level. The increases in yleld per plant as spacing was increased from 6 to 9 and from 9 to 12 inches were slightly greater than the yleld increase occurring as spacing was increased from 12 to 15 inches.

The variety $x$ spacing interaction was significant at the 10 per cent level and attributed largely to the inconsistent response of Blson and Triumph. 


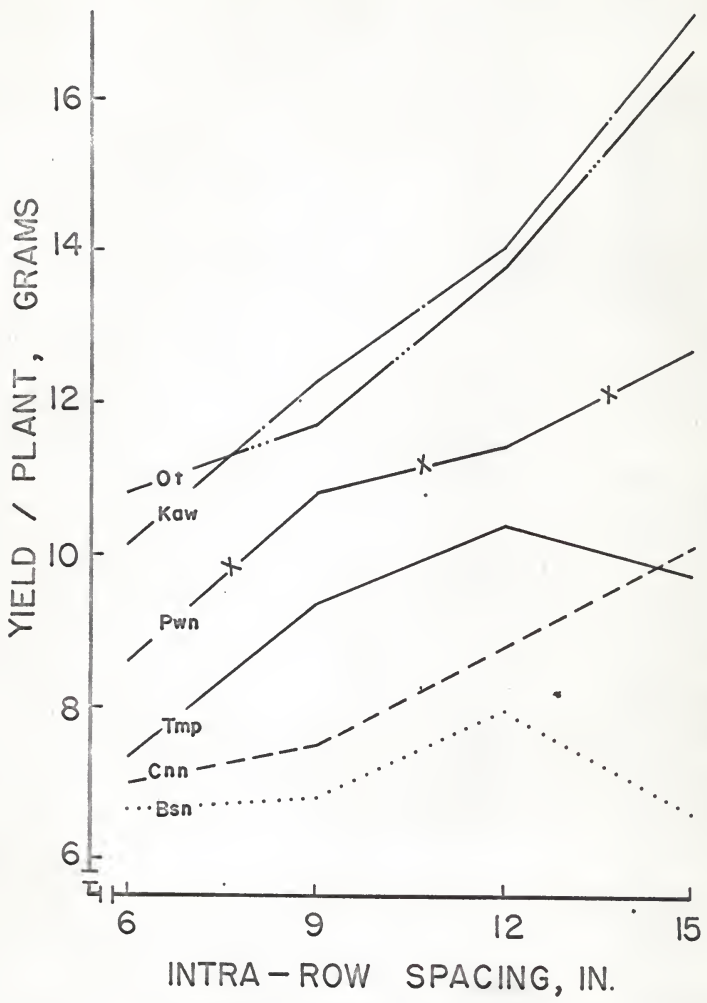

Figure 7. Influence of variety and plant spacing on grain
yield per plant. 
Table 9. Influence of variety and plant spacing on the yield per plant (grams).

\begin{tabular}{|c|c|c|c|c|c|c|c|}
\hline \multirow{2}{*}{ Variety } & \multirow{2}{*}{ : } & \multicolumn{4}{|c|}{ Intra-row spacing (inches) } & \multirow{2}{*}{$\vdots$} & \multirow{2}{*}{$\begin{array}{c}\text { Variety } \\
\text { mean }\end{array}$} \\
\hline & & 6 & 9 & 12 & 15 & & \\
\hline Bison & : & 6.65 & 6.82 & 7.89 & 6.61 & : & 6.99 \\
\hline Cheyenne & : & 6.99 & 7.49 & 8.76 & 10.12 & : & 8.34 \\
\hline Kaw & : & 10.12 & 12.25 & 14.05 & 17.14 & $:$ & 13.39 \\
\hline Ottawa & : & 10.86 & 11.70 & 13.82 & 16.66 & $:$ & 13.25 \\
\hline Pawnee & $:$ & 8.58 & 10.84 & 11.43 & 12.68 & : & 10.89 \\
\hline Triumph & $:$ & 7.31 & 9.32 & 10.36 & 9.77 & $:$ & 9.19 \\
\hline $\begin{array}{l}\text { Spacing } \\
\text { mean }\end{array}$ & $\vdots$ & 8.42 & 9.74 & 11.05 & 12.17 & $:$ & \\
\hline LSD at & & $\begin{array}{r}\text { Vari } \\
\text { Spa }\end{array}$ & $r s=$ & & & & \\
\hline
\end{tabular}

Variety Kaw Ottawa Pawnee Triumph Cheyenne Bison $\begin{array}{lllllll}\text { Ranking } & 13.39 & 13.25 & 10.89 & 9.19 & 8.34 & 6.99\end{array}$ $\begin{array}{lllll}\text { Spacing } & 15 & 12 & 9 & 6\end{array}$ Ranking $\quad 12.17 \quad \underline{11.05 \quad 9.74 \quad 8.42}$

Means underscored by the same line are not significantly (5\% level) different. 
Heads Per Sauare Foot. The Influence of variety and spacing on heads per square foot 18 presented in Figure 8 and Table 10. Differences due to varleties were significant at the 10 per cent level. The ranking in order of decreasing heads per square foot was Pawnee, Cheyenne, Ottawa, Kaw, Triumph, and B1son. All var1eties produced fewer heads per square foot as the distance between plants 1ncreased.

All spacing means were significantly different at the five per cent level. The number of heads per square foot decreased as the spacing increased. The reduction in the number of heads per square foot occurring when the distance between plants was increased from 6 to 9 inches was more than twice the reductions occurring as spacing was increased from 9 to 12 and 12 to 15 inches. There was no significant variety $x$ spacing interaction.

Number of Seeds Per Head. Data for th1s yield component appear in Figure 9 and Table 11. Varletal differences were signifleant at the one per cent level of probability. Ottawa had signiflcantly (flve per cent level) more seeds per head than the other varieties. Kaw had $81 \mathrm{gnificantly}$ more seeds per head than Bison and Cheyenne. Cheyenne produced significantly less seeds per head than all other varieties but Bison.

Differences in number of seeds per head due to spacing were not significant. There was no signiflcant varlety $x$ spacing Interaction.

Seed Weight. Seed weight data are shown in Figure 10 and Table 12. Seed weight of Kaw was signiflcantly greater than all the other varieties. Triumph and B1son were not algnificantly 


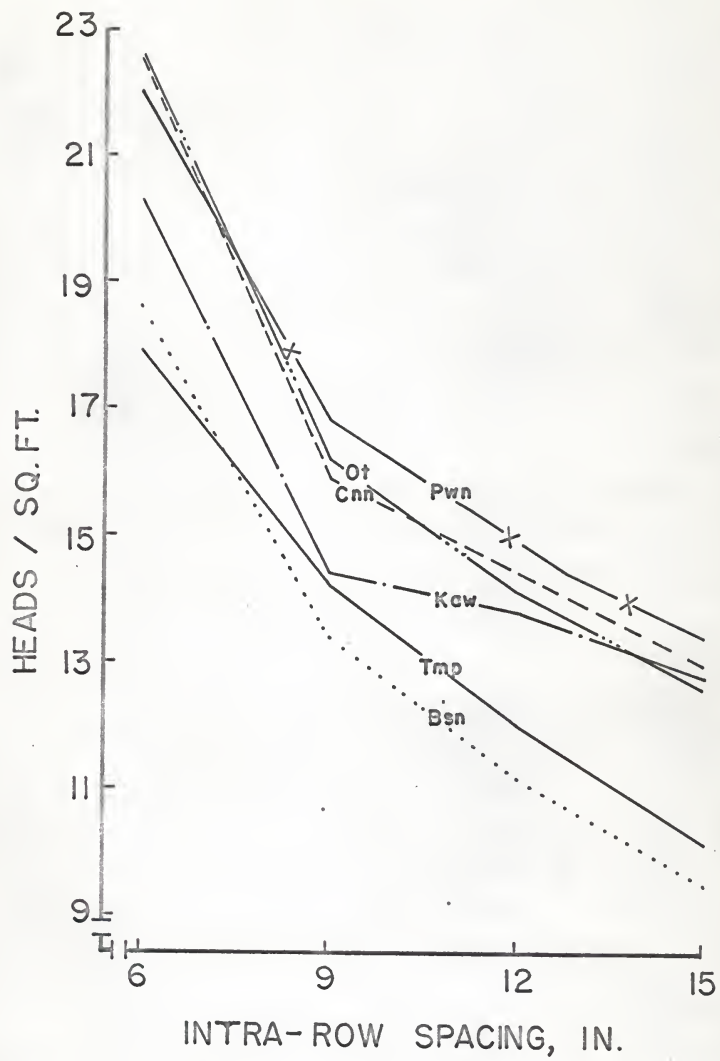

Figure 8. Influence of variety and plant spacing on number
of heads per square foot. 
Table 10. Influence of variety and plant spacing on the number of heads per square foot.

\begin{tabular}{lccccccc}
\hline Variety & $\vdots$ & \multicolumn{3}{c}{ Intra-row spacing (inches) } & Variety \\
\hline Bison & $\vdots$ & 6 & 9 & 12 & 15 & mean \\
Cheyenne & $\vdots$ & 18.6 & 13.4 & 11.2 & 9.5 & 13.2 \\
Kaw & $\vdots$ & 22.5 & 15.9 & 14.4 & 13.0 & 16.5 \\
Ottawa & $\vdots$ & 22.6 & 16.1 & 14.1 & 12.6 & 16.3 \\
Pawnee & $\vdots$ & 22.0 & 16.8 & 14.4 & 13.4 & 16.6 \\
Triumph & $\vdots$ & 17.9 & 14.2 & 12.0 & 10.1 & 13.6 \\
Spacing & $\vdots$ & 20.6 & 15.1 & 13.3 & 11.9 & $\vdots$ & \\
mean & $\vdots$ & & & & 13.8 & 12.8 & $\vdots$ \\
\hline
\end{tabular}

ISD at $5 \%$ level Spacings $=.9$

Variety Pawnee Cheyenne Ottawa Kaw Triumph Bison

\begin{tabular}{lllllll} 
Ranking & 16.6 & 16.5 & 16.3 & 15.3 & 13.6 & 13.2 \\
\hline
\end{tabular}

Spacing $\quad 6 \quad 9 \quad 12 \quad 15$

Ranking $\quad 20.6 \quad 15.1 \quad 13.3 \quad 11.9$

Means underscored by the same line are not significantly (5\% level) different. 


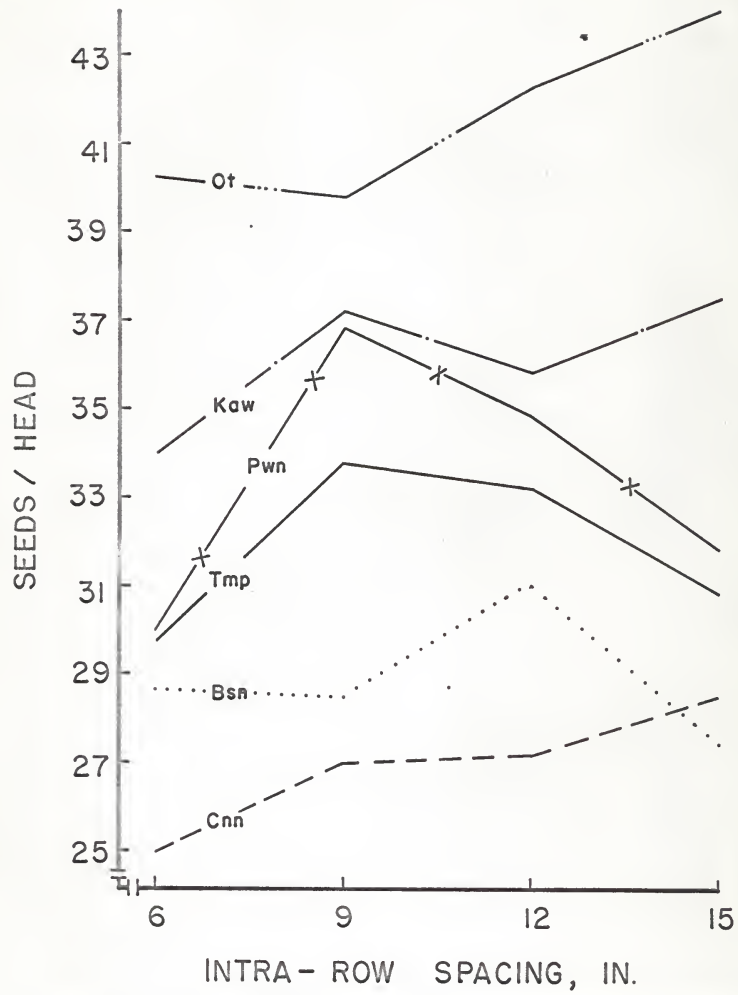

Figure 9. Influence of variety and plant spacing on number of seeds per head. 
Table 11. Influence of variety and plant spacing on number of seeds per head.

\begin{tabular}{|c|c|c|c|c|c|c|c|}
\hline \multirow{2}{*}{ Variety } & \multirow{2}{*}{ : } & \multicolumn{4}{|c|}{ Intra-row spacing (inches) } & \multirow{2}{*}{ : } & \multirow{2}{*}{$\begin{array}{l}\text { Variety } \\
\text { mean }\end{array}$} \\
\hline & & 6 & 9 & 12 & 15 & & \\
\hline Bison & : & 28.7 & 28.5 & 31.0 & 27.5 & : & 28.9 \\
\hline Cheyenne & : & 25.0 & 27.0 & 27.2 & 28.5 & : & 26.9 \\
\hline Kaw & : & 34.0 & 37.2 & 35.8 & 37.5 & : & 36.1 \\
\hline Ottawa & : & 40.2 & 39.8 & 42.2 & 44.0 & : & 41.6 \\
\hline Pawnee & $:$ & 30.0 & 36.8 & 34.8 & 31.8 & $\begin{array}{l}\vdots \\
:\end{array}$ & 33.3 \\
\hline Triumph & : & 29.8 & 33.8 & 33.2 & 30.8 & : & 31.9 \\
\hline $\begin{array}{l}\text { Spacing } \\
\text { mean }\end{array}$ & $\vdots$ & 31.3 & 33.8 & 34.0 & 33.3 & $\vdots$ & \\
\hline
\end{tabular}

LSD at $5 \%$ level Varieties $=4.5$

Variety Ottawa Kaw Pawnee Triumph Bison Cheyenne

$\begin{array}{llllll}\text { Ranking } \quad 41.6 \quad 36.1 & 33.3 & 31.9 & 28.9 & 26.9\end{array}$

Spacing $\quad 12 \quad 9 \quad 15 \quad 6$

Ranking $\quad \begin{array}{lllll}34.0 & 33.8 & 33.3 & 31.3\end{array}$

Means underscored by the same line are not significantly (5\% level) different. 


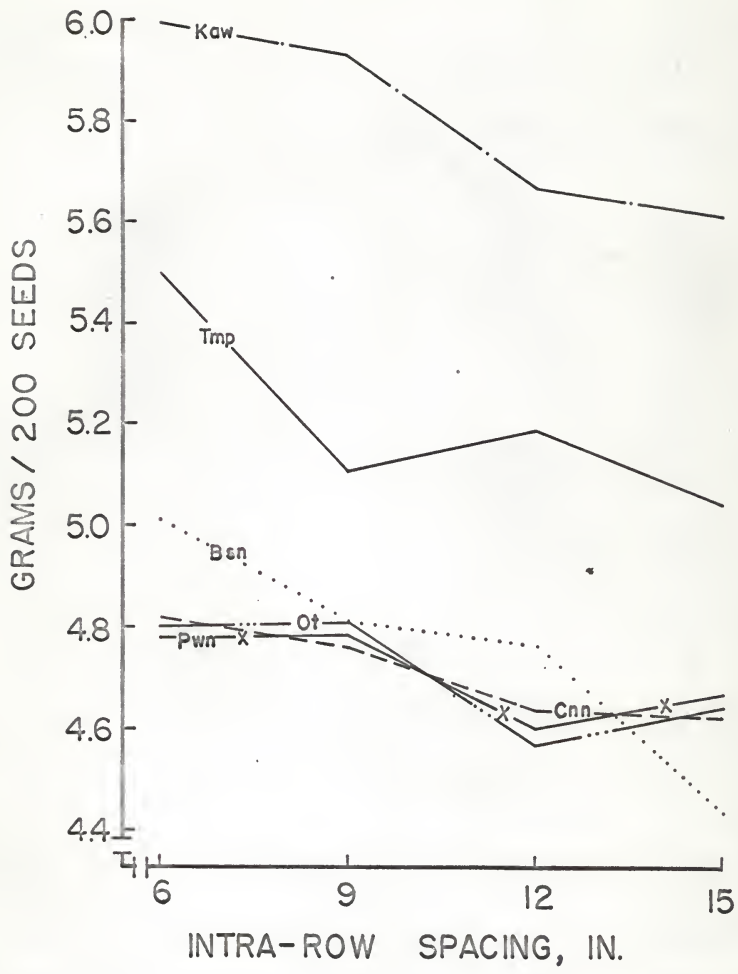
Figure 10. Influence of variety and plant spacing on seed
weight. 
Table 12. Influence of variety and plant spacing on the weight of 200 seeds (grams).

\begin{tabular}{lccccccc}
\hline Variety & $\vdots$ & \multicolumn{2}{c}{ Intra-row spacing (inches) } & $\vdots$ & Variety \\
& & 6 & 9 & 12 & 15 & mean \\
\hline Bison & $\vdots$ & 5.11 & 4.81 & 4.76 & 4.43 & $\vdots$ & 4.78 \\
Cheyenne & $\vdots$ & 4.82 & 4.76 & 4.63 & 4.62 & $\vdots$ & 4.71 \\
Kaw & $\vdots$ & 5.99 & 5.93 & 5.67 & 5.61 & $\vdots$ & 5.80 \\
Ottawa & $\vdots$ & 4.80 & 4.81 & 4.57 & 4.64 & $\vdots$ & 4.71 \\
Pawnee & $\vdots$ & 4.77 & 4.78 & 4.60 & 4.67 & $\vdots$ & 4.71 \\
Triumph & $\vdots$ & 5.50 & 5.11 & 5.18 & 5.04 & 5.21 \\
Spacing & $\vdots$ & 5.16 & 5.03 & 4.90 & 4.84 & $\vdots$ & \\
mean & $\vdots$ & & & & & &
\end{tabular}

ISD at $5 \%$ level Varieties $=.49$

$$
\text { Spacings }=.16
$$

Variety Kaw Triumph Bison Cheyenne Ottawa Pawnee

Ranking $\quad$\begin{tabular}{llllll}
5.80 & 5.21 & 4.78 & 4.71 & 4.71 & 4.71 \\
\hline
\end{tabular}

\begin{tabular}{lcccc} 
Spacing & 6 & 9 & 12 & 15 \\
Ranking & 5.16 & 5.03 & 4.90 & 4.84 \\
\hline
\end{tabular}

Means underscored by the same line are not significantly (5\% level) different. 
different; however, Triumph had significantly heavier seed than Cheyenne, Ottawa, and Pawnee. The seed welghts of Blson, Cheyenne, Ottawa, and Pawnee were not signiflcantly different. Bison, Cheyenne, and Kaw seed weights decreased with Increased spacing. This trend was also shown to a lesser extent by Ottawa, Kaw, and Triumph.

Differences between spacing means were significant at the one per cent level. Seed veight decreased slightly with increased spacing. The variety $x$ spacing interaction was insignificant.

Grain Protein Content. Figure 11 and Table 13 show Ottawa and Bison to have signiflcantly (five per cent level) higher protein content than Cheyenne, Pawnee, and Triumph. Bison and Kaw were not signiflcantly different. Kaw and Cheyenne were not significantly different, but Kaw protein percentage was significantly greater than Pawnee and Triumph. Ottawa and Triumph protein contents Increased with each increase in plant spacing. Bison and Pawnee showed an inconsistent trend toward more protein with increased spacing. Kaw decreased in protein up to the 12-inch spacing and then increased at the 15-inch spacing. Cheyenne increased in protein up to the 12-inch spacing then decreased at the 15-inch spacing.

Spacing means differed at the one per cent level. Protein content increased as speing increased. The variety $x$ spacing Interaction was significant at the 10 per cent level and was attributed to the inconsistent response of all the varieties except Ottawa and Triumph. 


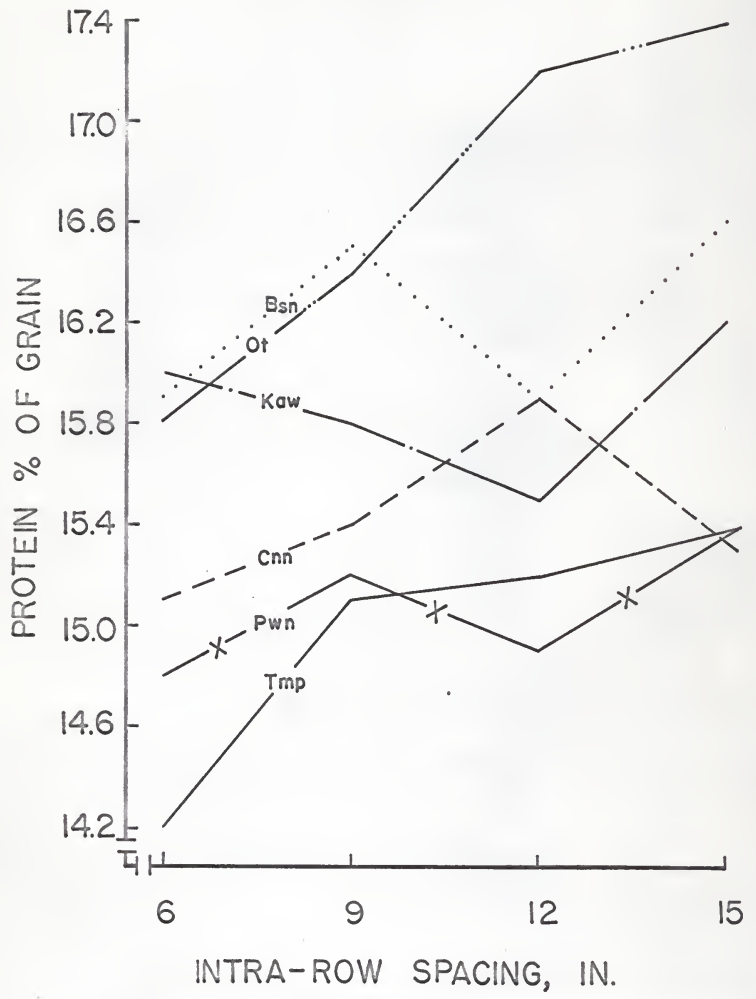

Figure 11. Influence of variety and plant spacing on protein percentage of grain. 
Table 13. Influence of variety and plant spacing on the protein percentage of grain.

\begin{tabular}{|c|c|c|c|c|c|c|c|}
\hline \multirow{2}{*}{ Variety } & \multirow{2}{*}{ : } & \multicolumn{4}{|c|}{ Intra-row spacing (inches) } & \multirow{2}{*}{$\begin{array}{r}\vdots \\
\text { : }\end{array}$} & \multirow{2}{*}{$\begin{array}{c}\text { Variety } \\
\text { mean }\end{array}$} \\
\hline & & 6 & 9 & 12 & 15 & & \\
\hline Bison & $\vdots$ & 15.9 & 26.5 & 15.9 & 16.6 & $\vdots$ & 26.2 \\
\hline Cheyenne & $\vdots$ & 15.1 & 15.4 & 15.9 & 15.3 & : & 15.4 \\
\hline Kaw & : & 16.0 & 15.8 & 15.5 & 16.2 & : & 15.9 \\
\hline Ottawa & : & 15.8 & 26.4 & 17.2 & 17.4 & $:$ & 16.7 \\
\hline Pawnee & : & 14.8 & 25.2 & 14.9 & 25.4 & $\vdots$ & 15.1 \\
\hline Triumph & $\vdots$ & 14.2 & 15.1 & 15.2 & 15.4 & $\vdots$ & 15.0 \\
\hline $\begin{array}{l}\text { Spacing } \\
\text { mean }\end{array}$ & $\vdots$ & 15.3 & 25.7 & 15.8 & 16.0 & $\vdots$ & \\
\hline
\end{tabular}

LSD at $5 \%$ level Varieties $=.7$

$$
\text { Spacings }=.3
$$

Variety Ottawa Bison Kaw Cheyenne Pawnee Triumph $\begin{array}{lllll}\text { Ranking } & 16.7 & 16.2 & 15.9 & 15.4 \\ \text { Spacing } & 15 & 12 & 9 & 6\end{array}$

\begin{tabular}{llll} 
Ranking $\quad 16.0 \quad 15.8$ & $15.7 \quad 15.3$ \\
\hline
\end{tabular}

Means underscored by the same line are not significantly (5\% level) different. 


\section{DISCUSSION}

In general, all the varleties tested showed increased yield as plant density increased. The exceptions occurred in the seeding rate experiment where Blson had depressed yleld at the 24 viable seeds per square foot rate and Cheyenne decreased In yield as the seeding rate was increased from 24 to 30 viable seeds per square foot. These yleld decreases were caused by poor stands for these rates in two replications of Bison and one of Cheyenne. These poor stands were caused by errors in seeding, rodent damage, etc.

Yield per plant increased as plant spacing increased; however, the accompanying reduction in plant density resulted in reduced yield. Naximum yields were obtained at either 24 or 30 viable seeds per square foot. These optimum rates are similar to those reported by Ahmed (1), Georgeson (10), and St1ckler (41) for this location but are slightly greater than those reported by Ten Eyck and Shoesmith (42).

The yield rankings for the two experiments were very similar. Pawnee and Triumph, and Cheyenne and Bison exchanged rank; however, their differences were insignificant at the five per cent level in both experiments. There was a highly significant (one per cent level) correlation $(r=.943)$ between varlety means of the two experiments, indicating that the relative yielding ability of varleties may possibly be predicted from space-planted trials. A previous study by Ahmed (1) conducted in 1961-62 did not show this similarity between the two experiments. This difference between the present and previous studies may be due largely to climatic 
and seeding date differences. The seeding date in Ahmed's study was September 27 and 29, and fall growing conditions were conducive for extensive tillering. In the present study, a planting date of October 9 resulted in a little more than one-half the number of tillers as occurred in the previous study. Molsture was limited in the latter part of the season. Thus, in a season with considerable environmental stress there were rather large differences in yield between the varleties in both the seeding rate and plant spacing experiments and a relatively close correlation between the two. The rather favorable season in the previous study resulted in little yleld differences between varieties in the seeding rate experiment and no significant yield differences between varieties In the plant spacing experiment and little correlation between the two.

Another point of interest regarding yield is the poor performance of Bison, Cheyenne, and Triumph at low plant densities and the ability of Kaw, Ottawa, and Pawmes to produce relatively high yiolds at low densities. This relationship in the seeding rate experiment could be largely due to the fallure of Bison, Cheyenne, and Triumph to establish the desired stands. However, the same relationship occurred with yleld per acre and yield per plant in the plant spacing experiment where desired stands were obtained by hand thinning.

The importance of linear, quadratic, and cubic effects of plant density on yield were determined by using orthogonal comparisons. Tield appeared to be largely a linear function of plant density, with the quadratic effect accounting for a much amaller 
(but significant) portion of the treatment sum of squares.

The yield data from these experiments Indicate the necessity of relatively high seeding rates for maximum yields of these six varieties and that there may be need for special emphasis on this point with Bison, Cheyenne, and Triumph.

Plant density had a marked influence on the number of heads per square foot. As the intra-row spacing was increased from $81 x$ to nine inches, there was a sharp roduction in the number of heads per square foot. The reduction in heads per square foot was less as the spacing between plants was increased to 12 and 15 inches. In the seeding rate experinent, Ottawa produced more heads per square foot than all the other varieties while Pawnee and Kaw produced slightly less and Bison, Cheyenne, and Triumph produced the least. However, as the plant density decreased Pawnee produced the greatest number of heads per square foot as shown in the plant spacing experiment. Cheyenne also moved up in rank to produce about the same number of heads per square foot as Ottawa with both being only slightly less than Pawnee. These changes in rank indicate varletal differences in tillering response with different plant densities. Burfum (4), Grantham (12), and Percival (35) suggest that the Inherent ablilty of a varlety to produce mature tillers is most easily recognized when the competition between plants is eliminated by wide spacing between individual plants. In regard to this concept, the present study would indicate that of the varletles tested, Ottawa had the greatest capacity to maintain Its inherent tillering ability as competition between plants increased, while the tillering of Cheyenne was greatly hampered by competition. 
This difference may have been caused by the fact that Ottaws is well adapted to northeastem Kansas whlle Cheyenne is less well adapted.

In the seeding rate experiment, the number of seeds per head was not signiflcantly influenced by variety. However, in the plant spacing experiment, there were marked differences among varlety means. In both experiments, the number of seeds per head increased slightly with decreased plant density (significant in the seeding rate experiment and insignificant in the plant spacing experiment).

There was a significant varlety $x$ seeding rate interaction In the seeding rate experiment. This was caused by the inconsistent response of all the varieties except Ottawa and Pawnee.

In the present study, the number of seeds per head in both experiments was almost twice the number reported in the earlier study by Ahmed (1). This was evidently associated with the greatly reduced tillering occurring in the present study. The results of these experiments are in agreement with the literature in regard to the influence of plant density or the number of heads per square foot on the number of seeds per head $(5,8,35,41)$.

Variety seed welght differences were significant in both experiments. Differences due to plant spacing were signiflcant whlle differences due to seeding rate were insignificant. In general, seed weight increased vith increased density. This was probably due to the smaller number of seeds per head occurring at the higher plant densities.

Simple and partial correlation coefficients for yleld and 
yield components are shown in Table 14. The partial correlation coefficients, which hold remaining components constant, show a significant positive correlation between yleld and all three of the yield components in both experiments. The greatest correlation was between yield and the number of heads per square foot in both experiments. This emphasizes the importance of establishing stands which will furnish a large number of heads per square foot. There were no significant correlations between any of the yield components. Another point of interest is the varietal differences in the contribution of the yield components to yield. The yields of Ottawe and Kaw were not significantly different in either experiment. However, Ottawa produced a greater number of heads per square foot and seeds per head than did Kaw in both experiments. Thus, the very high seed weight of Kaw enabled it to equal the yleld of Ottawa. Pawnee ranked high in the number of heads per square foot and the number of seeds per head, but its low seed weight resulted in only average yield. In the plant spacing experiment, Cheyenne ranked second in the number of heads per square foot but ranked fifth in yield because of low ranking in both the number of seeds per head and seed weight. All the yield components of Bison ranked low with resultant poor yleld in both experiments.

Varietal differences in grain protein content were much more evident in the plant spacing experiment than in the seeding rate experiment. Protein differences due to plant density were significant in both experiments. Protein content of the grain increased with decreased plant density. This was evidently because of the greater supply of soll nitrogen avallable per plant at the lower plant densities. 


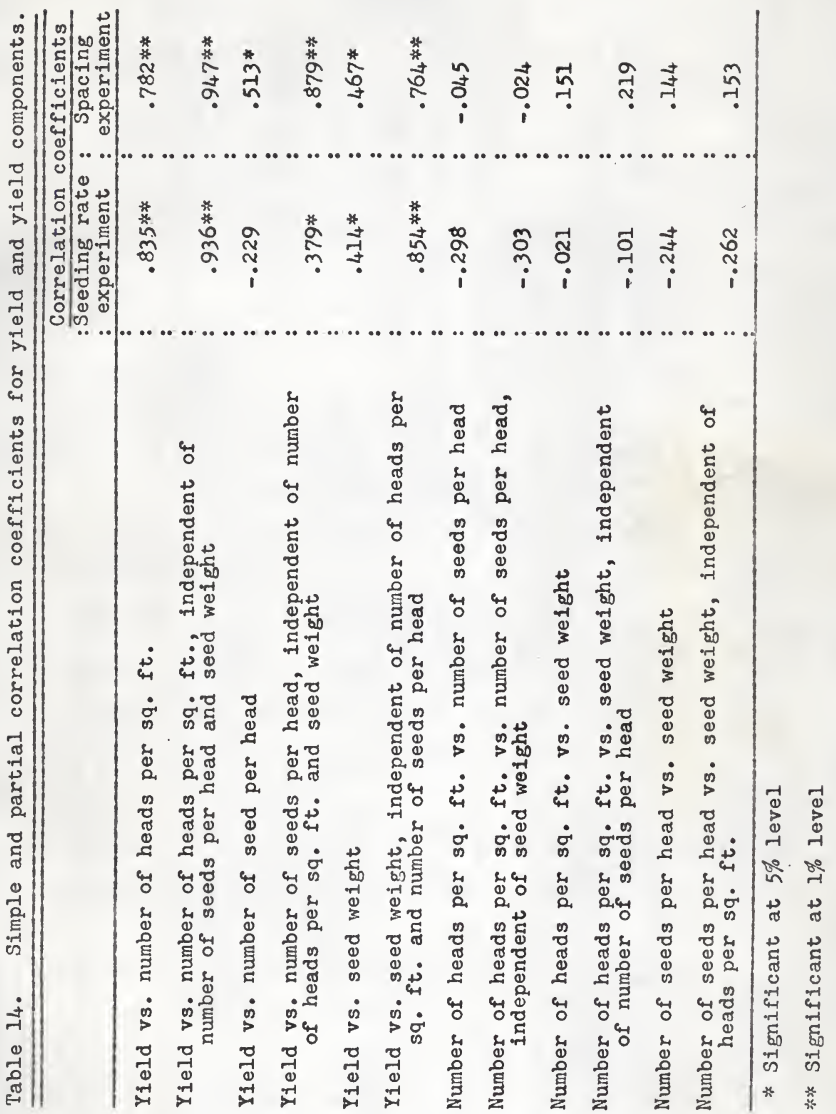




\section{SUMMART AND CONCLUSIONS}

In 1962-63 seeding rate and plant spacing study with six winter wheat varieties was conducted on the Agronomy Farm of the Kansas Agricultural Experiment Station, Nanhattan, Kansas. One experiment consisted of seeding rates of $6,12,18,24$, and 30 viable seeds per square foot. Plant spacings of $6,9,12$, and 15 inches in the row were employed in the other test. Twelve-inch rows were used in both tests. The varletles, Bison, Cheyenne, Kaw, Ottawa, Pawnee, and Triumph, were Included in both experiments.

Significant differences in grain yleld occurred among varieties in both experiments. The lowest yields in both experiments were those of Bison and Cheyenne. Ottawa and Kaw produced the highest ylelds in both experiments. The correlation of the variety means between the two experiments was highly significant $(r=.943)$. The similar varietal response of the two tests suggests that varietal yield performance in space-planted trials can sometimes be a good indication of fleld performance.

The seeding rate experiment showed that maximum yleld of all six varleties was highly dependent on relatively high seeding rates ( 6 or 7 pecks per acre). In both experiments, low plant density restricted the yield of Bison, Cheyenne, and Triumph more than the other three varieties. The results of this study suggest the desirability of seeding rates which result in high plant density and that there may be need of special emphasis on this point with certain varieties.

The number of heads per square foot increased with increased plant density and was closely assoclated with yield in both 
experiments. The number of heads per square foot was significantly influenced by varlety in the seeding rate test while the varietal differences were not signiflcant in the plant spacing teat.

The number of seeds per head increased slightly with decreased plant density in both experiments (81gniflcant only in the seeding rate experiment). The varietal means differed significantly in the plant spacing test and were insignificant in the seeding rate experiment.

Seed welght increased allghtly with increased plant density In both experiments (significant only in the plant spacing experiment). Varietal differences in seed weight were signifleant in both experiments.

All three yield components showed a significant positive correlation with yield in both experiments. There were no significant correlations anong the yield components.

Protein content of the grain increased significantly with decreased plant density in both experiments. Varietal differences in protein content were signiflcant in both experiments. 


\section{ACKNOWLEDGMENT}

The author is sincerely grateful for the valuable advice and assistance of his major professor, Dr. F. C. Stiekler, in carrying out the present study and in the proparation of this thesis.

Appreclation is expressed to Dr. A. W. Pauli for his kind direction in the use of laboratory facilities and to Dr. O.W. Bldwell for describing the soll on which the experiments were conducted. Gratitude is expressed to Dr. L. F. Marcus for his statistical advice.

Appreciation $1 \mathrm{~s}$ also expressed to Mr. M. A. Younis for his timely statiatical advice and assistance in the use of laboratory facilities. Thanks are also due to Mr. C. E. Meeks. 
1. Ahmed, M. K. Yleld and yield components of winter wheat as influenced by seeding rate and plant spacing. M.S. Thesis. Kansas State University L1brary, Manhattan, Kansas. 1962.

2. Bayless, B. B. and J. W. Taylor. Wheat production in the eastern United States. USDA Farmer's Bul. 2006:28. 1951.

3. Boyd, D. A. The effect of seed-rate on yleld of cereals. Emp1re J. Exp. Agr. 20:115-122. 1952.

4. Buffum, B. C. The stooling of grains. Wyoming Agr. Expt. Sta. Bul. 37. 1898.

5. Clements, F. E., J. E. Weaver, and H. C. Hanson. Plant Compet1tion. Carnegie Inst. Wash. Pub. 398. 1929.

6. Coffman, F. A. Experiments with cereals at the Akron (Colo.) field station in the 15-year period, 1908 to 1922, Inclusive. USDA Bul. 1287. 1925.

7. Engledow, F. L. Investigations on yield in cereals. II. a spacIng experiment with wheat. J. Agr. Sc1. 15:125-146. 1925.

8.

and $\mathrm{K}$. Ramiah. Investigations on yield in cereals. VII. a study of development and yield of wheat based upon varletal comparison. J. Agr. Se1. 20:265-344. 1930.

9. Forster, H. C, and A. J. Vasey. Investigations on yleld in the cereals, Victor1a. I. J. Agr. Sc1. 21:391. 1931.

10. Georgeson, C. C. Experiments with wheat. Kansas Agr. Expt. Sta. Bul. 59. 1896.

11. Glynne, M. D. and D. B. Slope. Effects of previous wheat crops, seed-rate and nitrogen on eyespot, take-all, weeds and yields of two varieties of winter wheat: Fleld experiment 1954-6. Ann. Appl. B101. 47:187-199. 1959.

12. Grantham, A. E. The effect of rate of seeding on competition in wheat varlet1es. J. Am. Soc. Agron. 6:124-128. 1914 .

13. The t1llering of wheat. Delaware Agr. Expt. Sta. Bul. 117:21-32. 1917.

14. Guitard, A. A., J. A. Newman, and P. B. Hoyt. The Influence of seeding rate on the yield and the yield components of wheat, oats, and barley. Canadian J. Plant Sc1. 41:751-758. 1961.

15. Hickman, J. F. Experiments with wheat. Oh10 Agr. Expt. Sta. Bul. $1: 50-52$. $188^{8}$. 
16. Hudson, H. G. Population studies with wheat. III. Seed rates in nursery trials and field plots. J. Agr. Sci. 31:138-144. 1931.

17. Jardine, W. M. Effect of rate and date of sowing on yleld of winter wheat. J. Am. Soc. Agron. 8:163-166. 1916.

18. Kiesselbach, T. A. Winter wheat investigations. Nebraska Agr. Expt. Sta. Res. Bul. 31. 1925.

19.

A. Anderson, W. E. Lyness. 14 years cultural practices in winter wheat production. Nebraska Agr. Expt. Sta. Bul. 286:24-25. 1934 .

20. Kinra, K. L., H. D. Foth, L. S. Robertson, and H. M. Brown. Effects of seeding rate, row spacing, and rate and placement of fertilizer on winter wheat performance. Agron. J. 55:24-27. 1963.

21. Latta, W. C. Field experiments with wheat. Indiana Agr. Expt. Sta. Bul. 27:7. 1889.

22. Laude, H. H., J. A. Hobbs, F. W. Smith, E. G. Heyne, and A. I. Clapp. Growing wheat in Kansas. Kansas Agr. Expt. Sta. Bul. $370: 22-23$. 1955 .

23. LeClerg, E. L., W. H. Leonard, and A. G. Clark. Fleld Plot Technique. 2nd'edition. Burgess Publishing Co. Minneapolis, Minnesota. pp. 188-190. 1962.

24. Leighty, C. E. and J. W. Taylor. Rate and date of seeding and seed-bed preparation for winter wheat at Arlington Experiment Farm. USDA Tech. Bul. 38. 1927.

25. Martin, J. H. Experiments with cereals on the Belle Fourche Experiment Farm. USDA Bul. 1039. 1922.

26. - Factors influencing results from rate- and dateof-seeding experiments with wheat in the western United States. J. Am. Soc. Agron. 18:193-225. 1926.

27. - and W. H. Leonard. Principles of Fleld Crop Production. The Macmillan Co. New York. pp. 489-491. 1949.

28. McDowell, R. H. Grain--thick and thin seeding. Potatoes-different dates of planting. Nevada Agr. Expt. Sta. Bul. 27:5. 1894 .

29. Montgomery, E. G. Competition in cereals. Nebraska Agr. Expt. Sta. Bul. 127:5-15. 1913.

30. Morrow, G. E. and J. H. Bone. Experiments with wheat 1896-7. Oklahoma Agr. Expt. Sta. Bul. 28:6-7. 1897. 
31. Morrow, G. E. and F. D. Gardner. Experiments with wheat 1891-92. Illinois Agr. Expt. Sta. Bul. 22. 1892.

32. Moss, W. A. Rate, date and depth of seeding winter wheat. Idaho Agr. Expt. St2. Bul. 145:4. 1926.

33. Nelson, C. E. Effects of plant population and nitrogen fertllizer rates on three varieties of 1rrigated spring wheat. Washington Agr. Expt. Sta. Bul. 611. 1960.

34. Pendleton, J. W. and G. H. Dungan. The effect of seeding rate and rate of nitrogen application on winter wheat varieties with different characteristics. Agron. J. 52:310-312. 1960.

35. Percival, John. The Wheat Plant. Duckworth and Co. London. pp. 421-432. 1921.

36. Rather, H. C. and C. M. Harrison. Field Crops. 2nd edition. MeGraw-Hill Book Co. New York. p. 277. 1951.

37. Snedecor, G. W. Statistical Nethods. 5th edition. Iowa State University Press. Ames, Iowa. 1956.

38. Stephens, D. E., M. A. McCall, and A. F. Bracken. Experiments in wheat production on the dry lands of the western United States. USDA BuI. 1173. 1923.

39. H. M. Wanser, and A. F. Bracken. Experiments in wheat production on the dry lands of Oregon, Washington and Utah. USDA Tech. Bul. 329. 1932.

40. Stewart, R. L. Wheat. New Mexico Agx. Expt. Sta. Bul. 109:5-6. 1918 .

41. Stickler, F. C. Row width and seeding rate as factors influencing winter wheat ylelds and components of yleld. Trans. Kansas Acad. Sc1. 64:1-6. 1961.

42. Ten Eyck, A. M. and V. M. Shoesmith. Small grain crops. Kansas Agr. Expt. Sta. Bul. 144. 1907.

43. Thatcher, L. E. Wheat cultural notes. Ohio Agx. Expt. Sta. No. Bul. 7:139-140. 1922 .

44. W1lson, J. A. and A. F. Swanson. Effect of plant spacing on the development of winter wheat. Agron. J. 54:327-328. 1962.

45. Zavitz, C. A. Forty years experiment with grain crops. Ontar10 Agr. College Bul. 332:20-21. 1927. 
RESPONSE OF CERTAIN WINTER WHEAT VARIETIES TO STAND DENSITY

by

JIMY MABRY

B. S., Texas Technological College, 1962

AN ABSTRACT OF A NASTER'S THESIS

submitted in partial fulfillment of the

requirenents for the degree

MASTER OF SCIENCE

Department of Agronomy

KANSAS STATE UNIVERSTTY

Manhattan, Kansas

1964 
There is a need for determining if the old well-established seeding rates are satisfactory for the newer varleties of winter wheat. Posalble differences in the seeding rate requirements of varleties, whether new or old, are also worthy of investigation. The performance of varieties in space planted studies as related to fleld performance is of particular interest to the plant breeder.

Therefore, seeding rate and plant spacing study with six winter wheat varieties was conducted on the Agronomy Farm of the Kansas Agricultural Experiment Station, Manhattan, Kansas. One experiment consisted of seeding rates of $6,12,18,24$, and 30 viable seeds per square foot. Plant spacings of $6,9,12$, and 15 Inches in the row were used in another test. Twelve-inch rows were used in both tests. The varieties, Bison, Cheyenne, Kaw, Ottawa, Pawnee, and Triumph, were included in both experiments. Signiflcant differences in grain yield occurred among varieties in both experiments. Ottawa and Kaw produced the highest yields in both tests. The lowest jield in both experiments were those of Bison and Cheyenne. The correlation of the variety means between the two experiments was highly significant $(r=.943)$. The similar varietal response of the two tests suggests that varietal yleld performance in space planted trials may be a good indication of field performance.

The seeding rate experiment showed that maximum yield of all six varieties was highly dependent on relatively high seeding rates ( 6 or 7 pecks per acre). In both experiments, low plant density restricted the yield of Bison, Cheyenne, and Triumph more than the other three varieties. The results of this study suggest 
the desirability of seeding rates which result in high plant density and that there may be need of special emphasis on this point with certain varieties.

The number of heads per square foot increased with increased plant density and was closely associated with yield in both experiments. The number of heads per square foot was significantly influenced by variety in the seeding rate test, but varietal differences were not significant in the plant spacing test.

The number of seeds per head increased slightly with decreased plant density in both experiments (significant only in the seeding rate experiment). The varietal means differed significantly in the plant spacing test and were insignificant in the seeding rate experiment.

Seed weight increased slightly with increased plant density in both experiments (significant in the plant spacing experiment and insignificant in the seeding rate experiment). Varietal differences in seed weight were significant in both experiments.

All three yield components showed a significant positive correlation with yield in both experiments. There were no significant correlations among the yleld components.

Protein content of the grain increased significantly with decreased plant density in both experiments. Varietal differences in protein content were significant in both experiments. 